\title{
Small scale Coffee Farmer's Response towards Management of Coffee Pest through Field Level Techniques
}

\author{
Bhanu Bhakta Panthi \\ Green Action Center-Nepal (Hariyali Kendra-Nepal) \\ Email: panthibrb@gmail.com
}

\begin{abstract}
Coffee among the Nepalese farmers is one of the breaks-through from the traditional subsistence food crops to agrobased industrial crop. It was planted under multi cropping pattern with fruits species; Musa paradiciaca L (banana), Citrus lemon (Lemon), Artocarpus heterophyllus (jack fruit), Pyrus pyrifolia (pear), and Psidium guajava L (guava), fodders species, cereals and vegetables. Coffee farmers of Gulmi and Lalitpur tried to manage the orchards through shade management, intercropping, optimum manuring, and protection from pests. For this, farmers adopted various management techniques; handpicking and destroying, use of local pesticides, use of pheromones trap. More than $90 \%$ of the coffee farmers were used local pesticides but with random composition and amount. Most preferred botanicals at farmer's level are; Allium sativum L., Allium cepa L., Azadirachta indica, Eupatorium adenophorum, Utrica dioca L. Artemesia indica, Zanthoxylum Zanthoxylum. Though, these techniques were applied, farmers still were not successful fully to overcome the problem of White Stem Borer (Xylotrechus quadripes). This might be due to untimely application and not proper composition to prepare in large quantity. This prepared pesticide was only effective to control small and soft bodied insects. The using of botanicals was observed to reduce the chances of pest attack and found a significant step toward green pesticides.
\end{abstract}

Keywords: Coffee farming, local pesticides, white stem borer (Xylotrechus quadripes), botanical pesticides

\section{INTRODUCTION}

Coffee is a potential and emerging commercial crop of Nepal. Nepalese coffee which is virtually free from inorganic fertilizers and pesticides could occupy good position among organic coffee in the world market. Nepal used to export only super quality beans to overseas markets; mostly to Japan, Germany, USA, Netherland and UK. The value of Nepalese coffee is high but the low degree of production may be attributed due to losses caused by various pests, diseases and poor management practices. The major insects damaging coffee in Nepal are WSB (Xylotrechus quadripes), larvae of Red Stem Borer, green scale, mealybugs and aphids. Grasshoppers, leafhoppers, hairy caterpillars, caseworms, tortoise beetles are also found as minor pests. Among all, WSB was the most problematic among others (NARC 2004).

Stem borers are the most destructive pests of arabica coffee in Asia and Africa. The larvae bore into stem causing death of young plants. The coffee WSB (Xylotrechus quadripes) was most serious pest of arabica coffee in India, Srilanka, China, Vietnam and Thailand (Jansen 2005, Venkatesha 1999). According to Jansen (2005) the major pests associated in Brazil (one third of total exports, i.e. $30.19 \%$ of world export) are leaf miners (Leucoptera coffeella), Coffee Berry Borer (Hypothenemus hampei), scales and mealybugs (Coccus viridis and Planococcus citri,), mites (Oligonychus coffeae) and nematodes. In India, it was estimated that over nine million trees were destroyed each year by WSB (X. quadripes). The WSB (Monochamus leuconotus) and the yellow stemborer (Dirphya nigricornis) can be found in different African countries as well.

Generally, pesticides used in coffee plantation are: Bordeaux mixture, copper sulfate, calcium oxide, deildrin, aldrin, fish oil, malathion etc. The most important pest is the Stem borer, Coffee Berry Borer mealybugs, scales, and nematodes in Ethiopia and Mexico. In Honduras, main pest problem is the Berry Borer, controlled normally by insecticide (endosulfan) applications. Lindane was recommended in India against WSB (Xylotrechus quadripes). Biological control as Beauveria bassiana is carried out to some extent. In Tanzania, stem cleaning was done to remove loose bark to reduce WSB eggs and spores present on the bark (Jansen 2005).

The most common chemical pesticides used in Colombia was endosulfan (Class II according to WHO classification), used against Coffee Cherry Borer. More than 100 human poisonings and one death during 1993 and more than 100 poisonings and three deaths in 1994 were attributed due to endosulfan, used in coffee. Colombia has considered endosulfan worse than the 
Coffee Cherry Borer. Broad spectrum organophosphates such as chlorpyrifos and diazion (Class II) were used against Coffee Cherry Borer and coffee leaf miner. It is a contact poison that caused human deaths, and also caused birth defects. Extremely hazardous organo-phosphates such as disulfoton and methyl parathion (Class 1a) were used against leaf miner. These pesticides were most toxic to birds, freshwater and marine organisms, bees, and other wildlife (www.coffeehabitat.com/2006/12/pesticides). The uses of these chemical pesticides in coffee farming possess environmental damages, unsustainable yield and financial burden. This finally produces negative impacts on human and health and the environment.

In Nepal, NARC (2004) estimated 20\% and 30\% crop losses due to pests in Kavre and Syangja districts respectively. WSB ( $X$. quadripes) is a major constraint for the successful coffee cultivation in Nepal (CoPP 2007, DCPA 2006). Orchard management, biological as well as chemicals (botanicals and synthetic chemicals) methods have been commonly practiced to protect crops from the insects and diseases. Still they cause great damages. Low degree of production might be due to loss caused by various pests and diseases, lack of shade, low nutrients and poor management practices (pruning, irrigation, and cultural operation).

In Nepal, Agricultural Perspective Plan has duly recognized Integrated Pest Management (IPM) as one of the priority agenda for sustainable agriculture also to fulfill the commitments made in Earth Summit held in Rio, Brazil in 1992. Realizing its potentiality, PPD/DOA have already given priority to create public awareness and started implementing effective IPM programs through FFS for proper, sound and judicious management of pesticides and control of hazardous chemical pesticides. The use of botanical pesticide is an important component of IPM strategy for major crops. The long term "Nepal Agricultural Perspective Plan" (APROSC/JMA 1995) being implemented from the $9^{\text {th }}$ 5-Year Plan (from 1997/98) by Government of Nepal and has also emphasized 'One of the main constraints in coffee cultivation is the loss of crop from diseases, insects, weeds, nematodes, mites, rodents and birds'.

Realizing that coffee orchard management is important for successful coffee cultivation, this study assesses the pest occurrence and management practices at farmer's field. Coffee producers of Gulmi, Palpa, and Lalitpur have reported White Stem Borer (X. quadripes) damage every year and though they practices different types of management techniques. This present study therefore focuses on insect's pest perceived by the farmers and field level techniques adopted by farmers to control pest.

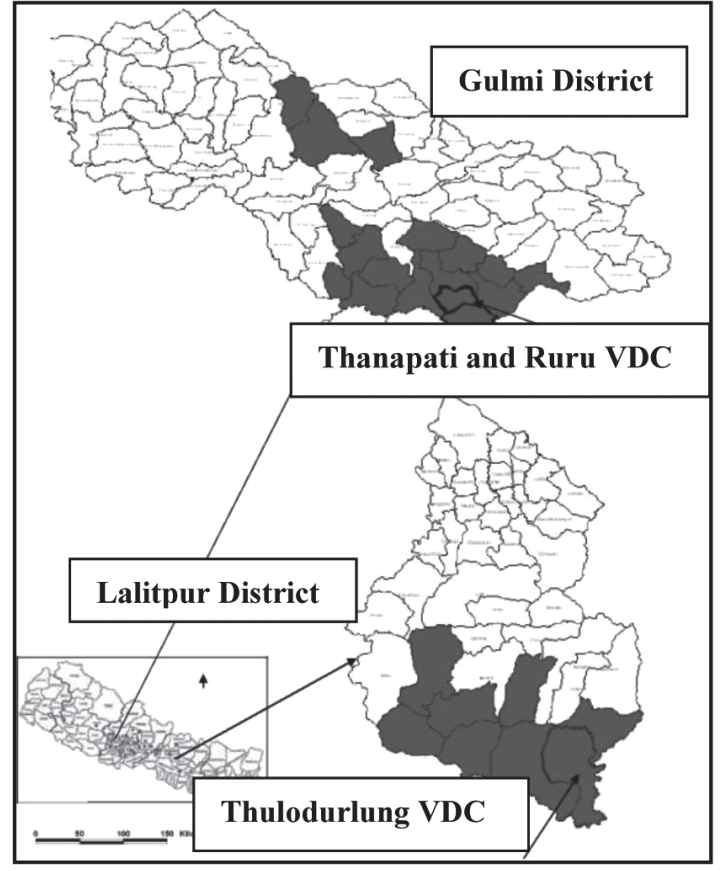

\section{MATERIALS AND METHODS}

The questionnaire survey was conducted in 8 Coffee Producer Groups of Thanapati and Ruru VDCs of Gulmi and 6 Coffee Producers Groups of Thulodurlung VDC of Lalitpur in November 2007. The farmers (34 farmers in Gulmi and 28 farmers in Lalitpur) were selected from these groups randomly. Respondents were also asked to rank pests according to extent of damages and the pest perceived by them in the coffee orchards. Other management aspects of irrigation and fertilizer application, intercropping and shade management in the field were studied through observation and questionnaires survey. The use of local botanicals, fodders and fruit trees within the coffee orchards for shade management were also recorded and identified from farmers and literatures (DMP/HMG 1986, Kayastha 2002, NARC 2004, Neupane 2000). The materials required at the time of field visit were killing pads, small tray, pointed forceps, labeling pens. The damage pattern and intensity of pests attack were observed directly in the field. And, trend in the use of pesticides and effectiveness of botanicals were asked directly with the coffee farmers.

\section{RESULTS AND DISCUSSION}

\section{Small Scale Coffee Farmers Perceptions on Insect Pests}

Protection of coffee plants from White Stem Borer and Red Stem Borer was serious in Gulmi and Lalitpur districts. Among all White Stem Borer was one of the most destructive pests on farmer's eye (ranked -1) as the most damaging. In the same way, Red Stem Borer 
(ranked -1) was also most damaging and mostly found in young stem and branches of old plants. But, farmers told that the adults of Red Stem Borer were rarely seen. Other pests of minor significance as perceived by small scale coffee farmers of Gulmi and Lalitpur were berry weevil, hairy caterpillars, aphids, red ant, white grub, nematodes and their ranking as shown in the table (1) .

Table 1. Insect pests as perceived by small scale coffee farmers

\begin{tabular}{|c|c|c|c|c|c|c|}
\hline Insect Pest & $\begin{array}{l}\text { Identification } \\
\text { from Farmers } \\
\text { Perspective } \\
\end{array}$ & $\begin{array}{c}\text { Time of } \\
\text { incidence }\end{array}$ & $\begin{array}{c}\text { Attacked } \\
\text { Part of Plant }\end{array}$ & $\begin{array}{c}\text { Out of } 62 \\
\text { orchards\% } \\
\text { infestation }\end{array}$ & Ranking & $\begin{array}{c}\text { Farmers Management } \\
\text { Practices }\end{array}$ \\
\hline $\begin{array}{l}\text { White Stem } \\
\text { Borer }(X . \\
\text { quadripes })\end{array}$ & $\begin{array}{l}\text { Locally used word as } \\
\text { Dhamiro infested }\end{array}$ & $\begin{array}{l}\text { March - } \\
\text { June }\end{array}$ & $\begin{array}{l}\text { Stem of old } \\
\text { plants }\end{array}$ & 88.70 & 1 & $\begin{array}{l}\text { Handpicking, Scrubbing } \\
\text { Pheromone's Trap, Local } \\
\text { pesticides }\end{array}$ \\
\hline $\begin{array}{l}\text { Red Stem } \\
\text { Borer }\end{array}$ & $\begin{array}{l}\text { Red larvae inside the } \\
\text { stem }\end{array}$ & March -June & $\begin{array}{l}\text { Branches of } \\
\text { young plants }\end{array}$ & 58.06 & 1 & $\begin{array}{l}\text { Handpicking, Scrubbing, } \\
\text { Pheromones Trap, Local } \\
\text { pesticides }\end{array}$ \\
\hline $\begin{array}{l}\text { Berry } \\
\text { Weevil }\end{array}$ & $\begin{array}{l}\text { Small black insect } \\
\text { on fruit }\end{array}$ & Aug-Dec. & Mature Fruits & 30.72 & 4 & No Measure \\
\hline Red Ant & Red ant & Oct. Dec. & Root/Stems & 30.64 & 2 & Local Pesticides \\
\hline Aphid & $\begin{array}{l}\text { Brown small sucking } \\
\text { insect }\end{array}$ & $\begin{array}{l}\text { June } \\
\text {-August }\end{array}$ & $\begin{array}{l}\text { Young } \\
\text { Leaves }\end{array}$ & 24.32 & 3 & Local Pesticides \\
\hline $\begin{array}{l}\text { Hairy } \\
\text { Caterpillar }\end{array}$ & Hairy larva on leaves & $\begin{array}{l}\text { April } \\
\text {-August }\end{array}$ & $\begin{array}{l}\text { Tender } \\
\text { Leaves }\end{array}$ & 33.87 & 4 & Local Pesticides \\
\hline White grubs & $\begin{array}{l}\text { Whitish body with } \\
\text { black head }\end{array}$ & April - Oct. & Roots & 30.64 & 2 & Local Pesticides \\
\hline Butterfly & $\begin{array}{l}\text { Small white flying } \\
\text { insect }\end{array}$ & Oct. - Dec. & $\begin{array}{l}\text { Young leaves } \\
\text { and buds }\end{array}$ & 23.27 & 4 & No Measure \\
\hline Nematodes & Whitish small insect & & Root/bark & 48.38 & 2 & Local Pesticides \\
\hline
\end{tabular}

Infested plants showed drying tendency with yellowing of the leaves and eventual falling off (Fig 1). The barks of the attacked trunk showed abnormal appearance and branches and twigs had circular cracks and symptoms of wilting due to damage of the main central conducting vessel (Fig 2). During the field visit, some of the plants were found heavily infested with 24 exit holes in a single plant with several tunnels packed with excreta. About 10-

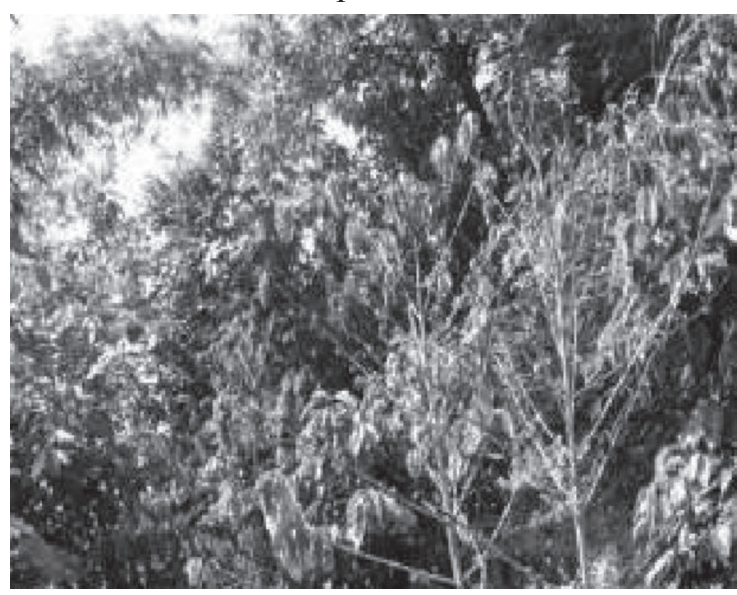

Fig. 1. Coffee stem borer infested orchard
12 larvae ranging from 2-4 $\mathrm{cm}$ in length and 1-2 adults of WSB were observed in a single plant during the field visit at Thanapati-5. The adult were about 1 to $2 \mathrm{~cm}$ long black with white bands (Fig. 3). Similarly, 14-16 exit holes of WSB with 8 larvae in a single plant were observed in coffee orchard of Silinge-6. Farmers reported that the magnitude of damage caused by the larval stage was particularly high as compared to the nymphs and adults.

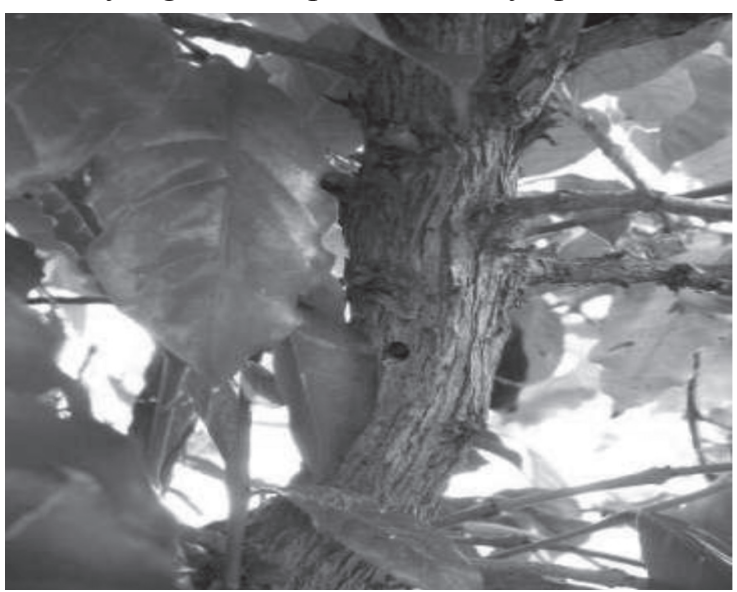

Fig. 2. White Stem Borer at the tip of hole 


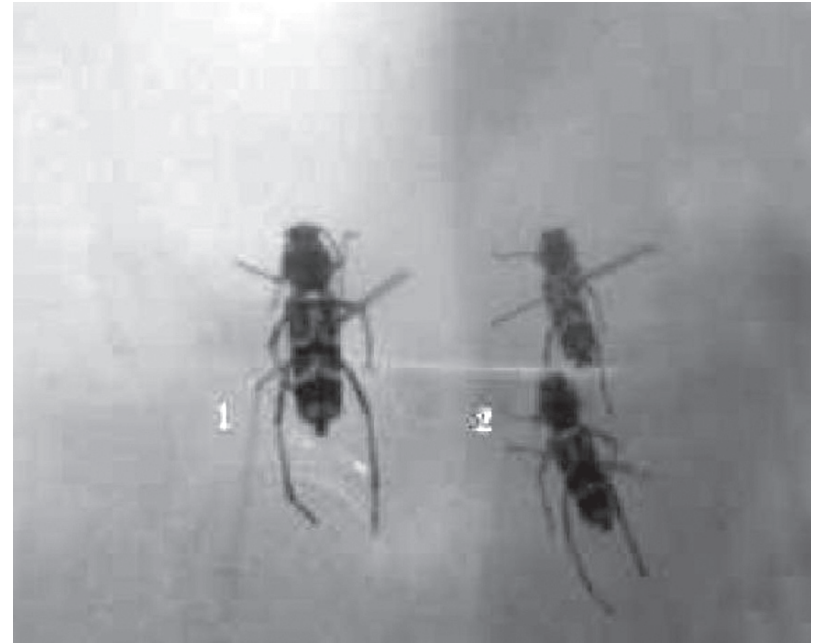

Fig. 3. White Stem Borer (Xylotrechus qud.)

Another destructive pest was Red Stem Borer. The larval stages were found in young stems/branches of the old plants, but the adults of the borer could not be found (Fig. 4). A single larva was found in a single plant when several stems of infected plants were checked. Larvae of RSB moved upward from the infected part. The plant was observed wilting and yellowing on the upper parts.

Coffee cultivation was found to be problematic due to WSB (Xylotrechus quadripes) and RSB in both districts. The infestations by WSB and RSB were found to be higher in Gulmi than in Lalitpur district. NARC (2004) also reported that WSB (Chlorophorus annulatus and $X$. smei) was observed in Syangja but not at different locations of Kavre district. NARC (2004) also reported that snails and beetle were problematic in Kavre and Syangja. In Gulmi and Lalitpur, these were also present in orchard, economically less importance in farmer's eyes as compared to stem borer. Farmer's viewed that other insects attacked on some parts (branches, leaves, twigs) whereas the stem borer was economically important because it killed the whole plant. Another major problem was root injuries (nematodes) in Gulmi and Lalitpur district. It was more might be due to lack of irrigation and inadequate nutrient. Since, water deficits for a long period of time led to permanent wilting; as a result the plant dried and died off.

\section{Small scale Farmers Field Level Management Techniques}

Small scale farmers field level management techniques are basically based on the use of botanicals along with other ingredient, management through irrigation and use of organic fertilizer, and management through shade and intercropping pattern.

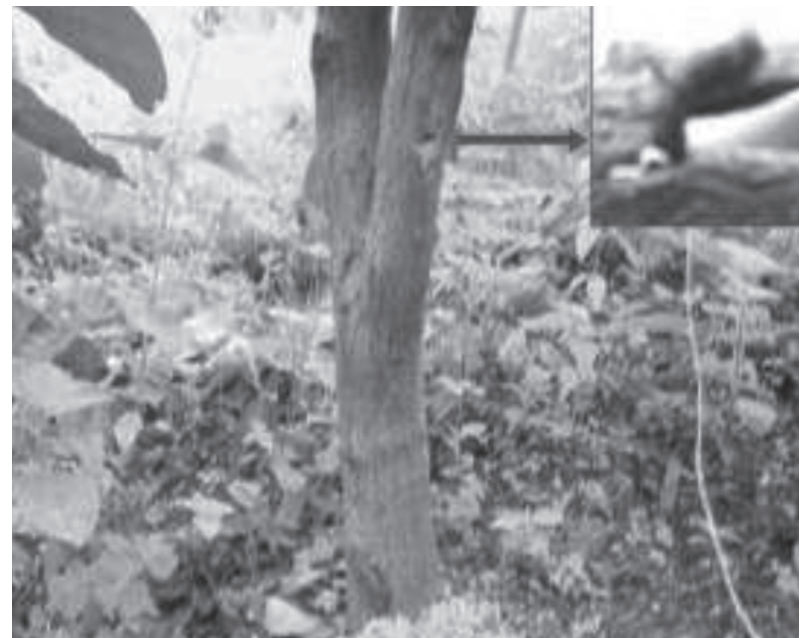

Fig. 4. Larva of Red Stem Borer

\section{Management through Shade and Intercropping Pattern}

Small scale farmers preferred to grow coffee in multicropping with fruits and fodder plants. Fruit plants were highly preferred for intercropping in both districts, which covered more than $33 \%$ of the coffee area followed by fodder $(>24 \%)$, cash crops $(>16 \%)$, vegetables $(>2.5 \%)$ and grasses $(>1 \%)$. Leguminous crops such as Pisum sativum L, Cajanus cajan, Vigna mungo L, Glycine $\max \mathrm{L}$ were also highly preferred by farmers because they believed these also improved nitrogen content of the soil. Majority of coffee farmers had small land holding and they were economically poor. So, they are getting maximum benefit from their limited land. Farmers of Lalitpur practices maize, millet, mustard and sugarcane along with coffee plant of age 1-3 yrs. in Lalitpur. Such practice of intercropping and shade maintenance possesses multiple benefits. FAO (1987) stated intercropping under agro forestry have ability to fix nitrogen, suitable for fodder, fast growing especially in early stages, easy adaptability in local environment, ability to withstand shading intensity, resistance to pests and multiplicity of function. Out of total coffee plants (200) sampled $50 \%$ each from shade and non shade, the infestation level was found to be $2.72 \%$ in shade condition and $12.27 \%$ in non shade condition. In Ruru, the infestation was lower because of proper shade, pruning and mulching practices. There was higher infestation in Thanapati where almost all orchards were without shade and poorly managed. This observation justified the major reason behind this higher infestation level. This is supported by Coffee manual (2003), which declared to have good shade maintenance, pruning, mulching and 
adequate nutrients to reduce the insect infestation level.

\section{Management through Irrigation and Use of Organic Fertilizer}

The availability of irrigation in coffee orchards in both districts was very limited; no farmer was found to have regular irrigation in orchards. It was major constraint especially during the flowering of coffee plants in both districts; the only alternative was to depend on rainwater. Sometimes, they used collection tanks and carried pots of water to irrigate their newly planted coffee orchards. According to the farmers, lack of irrigation was the major problem after diseases and pests in both districts.

Farmers used locally prepared organic fertilizer-cumpesticide 'jaibik bisadi'. Both coffee pulp and husk were also mixed with this product. Of the total farmers surveyed, 43\% used one 'doko' (20/25 kg) farmyard manure once in September and 57\% used $7 / 8 \mathrm{~kg}$ for larger and $3 / 4 \mathrm{~kg}$ for smaller plants two times during September and March. Coffee plants needs to have constant supply of nutrients at the time of flowering, fruiting and fruit development stages (CCRI 2007, MoAC 2004, and Coffee Manual 2003). Among total farmers surveyed, all farmers used farmyard manure, 55\% farmers used organic fertilizer-cum-pesticide and $12 \%$ used fermented green manures making a pit. None of the farmer was found using inorganic fertilizers.

\section{Use of Botanicals Along with Other Ingredient}

Management of insect pests has been done by mechanical; uprooting and destroying, use of pheromone and light trap, cultural; pruning and mulching, and local practices. Farmers uprooted the infested plants, cut off the part ad observed the level of infestation. Such branches were yellow and wilting and breaking from the infested region. Farmers destroyed the visible insects by killing or firing the cut off part. About $90 \%$ of the farmers were aware of this type of infestation and infested plants.

Pruning was highly practiced in $95 \%$ orchards in Ruru VDC, $25 \%$ of the orchards in Thanpati and $15 \%$ orchards in Thulodurlung VDCs. Farmers regularly checked weak, diseased branches and cut off. Farmers experienced that proper pruning reduced the chances of insect infestation. Mulching was also practiced in $90 \%$ of orchads in Ruru and $65 \%$ in Thanapati and $82 \%$ in Thulodurlung VDCs. Farmers used to cover soil surface with green resides around the coffee plants and noticed decaying. This process supplied organic manures. Mulching helped to improve soil fertility and suppressed soil borne diseases and pests attacks (CoPP 2004, Biswas \& Mukherjee 1994).

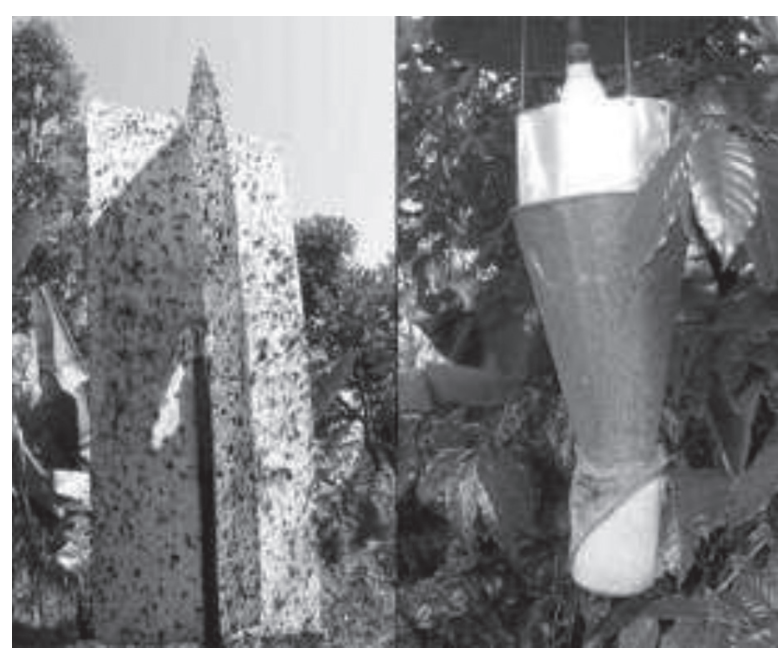

Fig.5 .Pheromone trap (left), light trap (right) fixed to control stem borer infestation

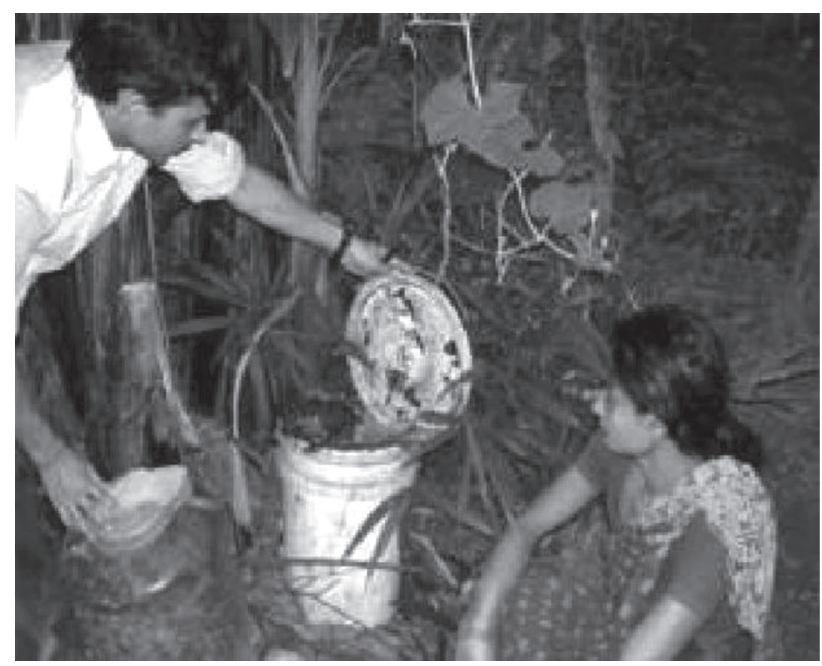

Fig.6. Locally prepared botanical pesticides to controls pest of coffee

There were 20 pheromone traps fixed in Thanapati and Thulodurlung VDC. Pheromone trap (Fig. 5 left) was effective to control White Stem Borer (X. quadripes) in Gulmi and Lalitpur because farmers reported that as high as 30 to 40 WSB ( $X$. quadripes) adults per day along with houseflies, bugs, grasshoppers were trapped. CoPP (2007) stated these traps were highly effective against $X$. quadripes when it is used in highly stem borer infested coffee orchards. In the field, farmers reported not only the stem borers but also some beneficial insects such as honey bee, butterflies were also trapped. Light trap (electric light) was not found as effective as pheromone traps. There were 3 light traps fixed at Thanapati and 4 in Thulodurlung VDC (Fig. 5 right). Farmers told light traps have been fixed in orchards since 3 months, where many species of butterflies, moths, grasshoppers, flying 
insects were trapped but not a single specimen of stem borer could be caught (Fig.5 right). Except in occasional cases, such traps were not found effective and used in the field in both the districts.

About $90 \%$ of the coffee farmers knew the toxic effects of chemical pesticides and the risks involved along with their uses. In this regard they applied local practices; mixture of cattle urine and Agava extract was used by $60 \%$ farmers in Gulmi and Lalitpur but Azadirachta indica (Neem) oil by only $11.76 \%$ farmers in Gulmi and $5.88 \%$ in Lalitpur. Utrica dioca L. 'Sisnoo metacid' was used by $71 \%$ of farmers in Lalitpur and Gulmi (44\%); mixture of Agava and Artemisia extract was used by $50 \%$ farmers in Gulmi and more 57\% farmers in Lalitpur. Coffee farmers collected plants having alkaloids or steroids with bitter or hot taste and prepare botanical pesticides (Table 2).

Table 2. List of local plants available to prepare botanical pesticides

\begin{tabular}{|c|c|c|c|c|c|}
\hline Local name & Common name & Scientific name & $\begin{array}{l}\text { Used in the } \\
\text { form of }\end{array}$ & $\begin{array}{l}\text { Farmer's way of } \\
\text { using }\end{array}$ & \begin{tabular}{|l} 
Usefulness on \\
Farmer's eye
\end{tabular} \\
\hline Aamala & Emblic & Emblica officinalis L. & Fruits & Buried into soil & Effective \\
\hline Aangeri & Drude & Lyonia ovalifolia & Leaves/buds & Water extract & Effective \\
\hline Aasuro & Adhatoda & Justicia adhatoda L. & Leaves & Water extract & Effective \\
\hline Aduwa & Ginger & Zingiber officinale & Bulb & Water extract & Very Effective \\
\hline Bakainu & China berry & Melia azedarach & Fruits, leaves & Water extract & Very Effective \\
\hline Banmara & Siam weed & Eupatorium adenophorum & Sooth, leaves & Water extract & Effective \\
\hline Bojho & Sweet flag & Acorus calamus L. & Root & Powder & Rarely used \\
\hline Chiuri & Bachni & Bassia-butyracea & Oilcake & Water extract & Rarely used \\
\hline Dhaturo & Angel trumpet & Datura metel L. & Fruits, leaves & Water extract & Rarely used \\
\hline Kagati & Lemon & Citrus limon L. & Fruit & Water extract & Rarely used \\
\hline Kantakari jhar & & Solanum aculeatissinum & Leaves & Water extract & Effective \\
\hline Ketuke & Century plant & Agava americana $\mathrm{L}$. & Leaves & Water extract & Effective \\
\hline Khirro & Tallow tree & Sapium insigne & Leaves & Water extract & Effective \\
\hline Khursani & Chilli & Capsicum frutescens $\mathrm{L}$. & Fruit & $\begin{array}{l}\text { Water extract/ } \\
\text { Powder }\end{array}$ & Effective \\
\hline Lasun & Garlic & Allium sativum L. & Bulb & Water extract & Effective \\
\hline Neem & Neem tree & Azadirachta indica & Seeds, leaves & Water extract & Effective \\
\hline Pudina & Field mint & Mentha arvensis L. & Leaves & Water extract & Rarely used \\
\hline Pyaj & Onion & Allium cepa L. & Bulb & Water extract & Effective \\
\hline Rato Sirish & Red Siris & Albizia julibrissin & Leaves & Water extract & Very Effective \\
\hline Sisnoo & Stinging nettle & Utrica dioca $\mathrm{L}$. & Whole plant & Water extract & Effective \\
\hline Siudi & Cactus & Opuntia spp. & Whole plant & Water extract & Effective \\
\hline Surti & Tobbaco & Nicotiana tabacum & Leaves & Water extract & Rarely used \\
\hline Timur & Prickly ash & Zanthoxylum armatum DC. & Fruits & $\begin{array}{l}\text { Water extract/ } \\
\text { Powder }\end{array}$ & Very Effective \\
\hline Titepati & Mug wort & Artemesia indica & Leaves & $\begin{array}{l}\text { Water extract/ } \\
\text { Buried in soil }\end{array}$ & Very Effective \\
\hline Tori & Mustard & Brassica campestris & Oil's cake & Water extract & Very Effective \\
\hline
\end{tabular}

Mixture of cattle dung, red soil and Bordeaux mixture (BM) was practiced more in Gulmi than in Lalitpur, because some farmers in Lalitpur replied that these were earlier practices which did not work effectively. After scrubbing coarse bark of coffee plant with 'Jute mattresses' or hard course materials one or more of the following practices were applied to control pests.
Generally, Agava americana L. (Ketuki) extract and cattle urine was applied every week but others were applied every month. Under farmer's practices cattle urine and Agava americana extract applied on stem, Azadirachta indica (Neem oil), Bassica-butyracea (oilcake) with cattle urine, red soil and cattle dung was used on stem of plants. Similarly, fresh cattle dung (kancho gobar) mixed 
with green leaves of plants dipped in water in drum for 10 to 15 days. Utrica dioca L. 'Sisnoo metacid' (Sisnoo extract); $1 \mathrm{~kg}$ of fresh leaves was dipped in 8/9 liters of water for 14 to 18 hours for good extraction and was applied. Paste of 'Artemesia indica 'Ketuki' $(1 \mathrm{~kg})$ and 'Agava americana L.'Titepati' $(2 \mathrm{~kg}$ ) were taken and chopped into small pieces, mixed with 5 litre of water and put in drum for about 15 days for aqueous extraction. Further, it was diluted with 10 litre of water for spraying. Fresh leaves of Artemesia indica, Sapium insigne Agava americana L., Eupatorium adenophorum 'kale jhar' were chopped into small pieces, and buried directly into soil before ploughing.

In general, coffee farmers collected some 10 to 12 plants available in the vicinity. These collected botanicals were chopped into small pieces and mixed up. Then, this was diluted with water and put into a plastic drum (usually 50 liters capacity) and allowed to ferment for 18-22 days. In one liter of the fermented liquid farmers added 8 liters of water before spraying on coffee plants in both the districts. For increasing the effectiveness of this, farmers used fermented liquid along with water and cattle urine in a ratio of (1:5:1) and mixed thoroughly before spraying on coffee plants.

Generally, farmer's used botanical pesticides randomly without the proper composition and amount. It was done by simply collecting the available plants found in their vicinity. Though, the application of local pesticide reduced chances of infestation level, not fully succeed to overcome problem of stem borer. This might be due to lack of research on proper composition and effectiveness at field and laboratories. Neupane (2003) stated that only 45 species of botanicals have been tested so far in Nepal against some insect pests. These local practices are randomly undertaken not as per the exact timing of application. In some cases, eggs of White Stem Borer (X. quadripes) were still within the region of pasted part leading to failure of practice (CoPP 2004). This might reduce the efficiency. The use of self prepared botanical pesticide was found effective not only to minor pest of coffee but also increased the organic matter in addition to active alkoids/steroids (Panthi et. al., 2008).

\section{CONCLUSION}

Majority of the coffee farmers did not report any serious insect, except adult and larvae of WSB (Xylotrechus quadripes) and larva of RSB (larvae only). Other insects were less damaging and could be managed by applying local pesticides. Among various insect pests damaging the branches, leaves and twigs, the stem borer was economically important because it killed the whole plant. Farmers applied various measures; mechanical, cultural and use of local techniques to reduce the economic losses. Under these techniques; use of pheromone traps, application of mud, red soil cattle urine in stem along with environment friendly materials. One of the useful ingredient used was garlic (2-4 pcs), chilli (dry $15 \mathrm{~g}$ ), onion (1-2 bulbs) and mustard cake (1/2 kg) proceed into a fine paste, and then boiled in 4-5 liters of water for 15 to 20 minutes. This served as an excellent pesticide against small and soft bodied insects. Interestingly, coffee farmers were using botanicals in crude form and found satisfactory results for minor pests except White Stem Borer and Red Stem Borer. Farmers also experienced that these pesticide mixtures drenched into the soil were effective in killing harmful insects (ants, and white grubs). Thus, the use of local botanical pesticide was found not only to control the pests, but also significant step in organic coffee production.

\section{ACKNOWLDGEMENTS}

The author would like to express sincere and hearty gratitude to Dr. Bhupendra Devkota, Entomologist, and Mr. Prachanda Man Shrestha, Team leader, Coffee Promotion Program (CoPP)/Helvetas for supervision and technical support. The author is also thankful to District Coffee Producers Association (DCPA) Gulmi, DCPA Lalipur, and Nepal Agriculture Research Council (NARC), Entomology division, Khumaltar. The author wishes to express gratitude to Ecoinitiatives-Nepal, Hariyali Kendra- Nepal for smoothly facilitating this research work.

\section{REFERENCES}

APROSC/JMAI 1995. Nepal agriculture perspective plan. Agricultural Projects Services Centre (APROSC), Kathmandu, Nepal and John Mellor Associates Inc. (JMAI), Washington, DC. USA.

Biswas, T.D. and Mukherjee, S.K. 1994. Textbook of soil science. $2^{\text {nd }}$ Edition. Tata Mc Graw-Hill publishing Company Limited. West Patel Nagar, New Delhi.

CCRI 2007. Soil diagnostic norms for arabica coffee cultivation. Department of soil, Central Coffee Research Institute, Chickmaglure district, Karnataka State, India.

CoPP 2007. Study of winter season emergence of white stem borer from infested cut plants. Coffee Promotion Program, Helvetas, Bakhundol, Lalitpur, Nepal.

DCPA 2006/07). Annual progress report. District Coffee Producer's Association, Tamghas, Gulmi, Nepal.

DMP 1986. Flora of Kathmandu valley. Department of Medicinal Plants. His Majesty's Government of Nepal, Kathmandu.

FAO 1987. Nitrogen-fixing trees-a training guide. Food and Agricultural Organization of the United Nations. Rome. 
NTCDB 2003. Coffee manual. National Tea and Coffee Development Board in collaboration with Winrock Internatonal Nepal, Tree Crop Global Development Alliance (NTCGDA). Central Office, New Baneshwor, Kathmandu.

CoPP 2007. Study of winter season emergence of white stem borer from infested cut plants. Coffee Promotion Program, Helvetas, Bakhundol, Lalitpur, Nepal.

CoPP 2005. Annual progress report. Coffee Promotion Project / Helvetas. Bakhundol, Lalitpur, Nepal.

Kayastha, B.P. 2002. A handbook of trees of Nepal (Timber, Fodder, Fruit, Medicinal, Ornamental, Religious). Laligurans Printing Press. Babarmahal, Kathmandu, Nepal.

MOAC 2004. Categorization of major nutrients required for the plant. Ministry of Agriculture and Cooperatives. Crop Development Directorate. Soil Testing and Service Section, Harihar Bhawan, Lalitpur.

NARC 2004. A joint report on diseases and insect pests of coffee in Nepal. Joint report by Nepal Agriculture Research Council and Coffee Promotion Program (CoPP), Helvetas, Nepal.
Neupane, F.P. 2000. Jadibutidwara Kira Niyantran (Insects control with botanicals). Sajha Prakashan, Pulchok, Lalitpur.

Jansen, E.A. 2005. Common code for the coffee community. Deutsche Gesellschaft fur Technische Zusammenarbeit (GTZ) GmbH, Germany.

Panthi, B.B; Devkota, B., Devkota, U. J. 2008. Effects of Botanical Pesticides on Soil Fertility of Coffee Orchards. Ministry of Agriculture and Cooperative, Kathmandu. The Journal of Agriculture and Environment. Vol. 9.P20.

Ventketsha, M.G. 1999. Tactful management of white stem borer. Indian coffee monthly magazine. Coffee Board of India (www.indiancoffee.com/ publications/2007).

www.coffeehabitat.com/2006/12/pesticides, Environment and Conservation: pesticides used on coffee farms. 